\title{
Susceptibility to peroxidation and fatty acid composition of fresh boar semen obtained from different hog farms
}

\author{
Marmunti, M.'; Gutiérrez, A.M.1,2; Gavazza, M.'; Williams, S.3; Palacios, A. ${ }^{1}$ \\ Cátedras de Bioquímica ${ }^{1}$, Fisiología ${ }^{2}$ y Reproducción Animal ${ }^{3}$, Facultad de Ciencias Veterinarias, Universidad \\ Nacional de La Plata, Calles 60 y 118, CC296, B1900 AVW, La Plata, Buenos Aires, Argentina. \\ Tel: +54 221 4236663; fax: +54 221 4257980. E-mail: monicamarmunti@yahoo.com.
}

\begin{abstract}
Marmunti, M.; Gutiérrez, A.M.; Gavazza, M.; Williams, S.; Palacios, A.: Susceptibility to peroxidation and fatty acid composition of fresh boar semen obtained from different hog farms. Rev. vet. 23: 1, 8-14, 2012. Objectives of this study were to determine the fatty acid composition and to analyze the sensitivity to lipid peroxidation of different boar fresh semen samples from two herds, $\mathrm{H} 1$ and H2. Lipid peroxidation was evaluated using chemiluminescence (cpm/mg of protein) and fatty acid profile by means of gas chromatography. The saturated fatty acid content found in the analyzed spermatozoa was approximately $43 \%$ in $\mathrm{H} 1$ and $33 \%$ in $\mathrm{H} 2$, whereas the total unsaturated fatty acid content was $47 \%$ in $\mathrm{H} 1$ and $59 \%$ in $\mathrm{H} 2$. When control and ascorbate- $\mathrm{Fe}^{++}$dependent samples were compared, it was observed a significant increase in light emission. Consequently, significant decrease in the percentage of the polyunsaturated fatty acids was determined, being more affected: C22: $5 \mathrm{n} 6$ and C22: 6 $\mathrm{n} 3$ in both herds, whereas C20: $4 \mathrm{n} 6$ and C22: $4 \mathrm{n} 6$ only in H2. The great amounts of polyunsaturated fatty acids found in $\mathrm{H} 2$ samples could be related to the loss of acrosomal integrity. Our results indicate that boar semen contains great amounts of polyunsaturated fatty acid in its composition, which were vulnerable to the lipid peroxidation.
\end{abstract}

Key words: boar, spermatozoa, chemiluminescence, polyunsaturated fatty acids, reactive oxygen species.

\begin{abstract}
Resumen
Marmunti, M.; Gutiérrez, A.M.; Gavazza, M.; Williams, S.; Palacios, A.: Susceptibilidad a la peroxidación lipídica y composición de ácidos grasos de semen porcino obtenido de diferentes establecimientos. Rev. vet. 23: 1, 8-14, 2012. El objetivo de este estudio fue conocer la composición de ácidos grasos y la sensibilidad a la peroxidación lipídica en diferentes muestras de semen fresco porcino de dos granjas, GP1 y GP2. La peroxidación lipídica fue evaluada utilizando quimioluminiscencia ( $\mathrm{cpm} / \mathrm{mg}$ de proteína) y el perfil de ácidos grasos fue valorado por cromatografía gaseosa. El porcentaje de ácidos grasos saturados hallado en los espermatozoides analizados de GP1 y GP2 fue de 43 y 33\% aproximadamente, mientras que el porcentaje total de ácidos grasos insaturados fue de $47 \%$ en GP1 y $59 \%$ en GP2. Cuando se compararon las muestras control con las muestras ascorbato- $\mathrm{Fe}^{++}$dependientes, se observó un incremento significativo en la emisión lumínica. Consecuentemente se obtuvo una disminución significativa en el porcentaje de los ácidos grasos polinosaturados, siendo los más afectados C22: 5 n6 y C22: 6 n3 en ambos establecimientos, mientras que sólo C20:4 n6 y C22:4 n6 en GP2. La mayor cantidad de ácidos grasos polinosaturados en GP2 guardó relación con una menor calidad seminal, medida sobretodo en el porcentaje de acrosomas normales. Los resultados indican que el semen porcino contiene grandes cantidades de ácidos grasos polinosaturados vulnerables a la peroxidación lipídica.
\end{abstract}

Palabras clave: cerdo, espermatozoides, quimioluminiscencia, ácidos grasos polinosaturados, especies reactivas del oxígeno.

\section{INTRODUCTION}

In aerobic organisms oxygen is essential for life but it can also be toxic in some favorable situations in

Recibido: 20 febrero 2012 / Aceptado: 26 marzo 2012 which an exaggerated production of reactive oxygen species (ROS, superoxide anion $\mathrm{O}_{2}^{-}$and hydroxyl ${ }^{-} \mathrm{OH}$ ) takes place. Another possibility is the generation of hydrogen peroxide $\left(\mathrm{H}_{2} \mathrm{O}_{2}\right)$, a ROS that can be precursor of free radicals. ROS contribute to molecular and structural damage which occurs in many foods where the 
antioxidant capacity of the organism (antioxidants and enzymes) is surpassed and therefore unable to inactivate them, giving rise to the oxidative stress process ${ }^{17}$.

The oxidative damage in the cell membrane is induced by free radicals that lead to lipoperoxidation. During the metabolism of spermatozoa, the mitochondria generate unavoidably ROS that are inactivated by antioxidative mechanisms ${ }^{17}$. Lipid peroxidation may cause loss of membrane integrity, which increases its permeability that leads to enzyme inactivation, structural damage to DNA and cell death. Mammal spermatozoa are particularly susceptible to lipid peroxidation-induced damage because they contain high levels of polyunsaturated fatty acids and lack of antioxidant enzymes, such as superoxide dismutase, glutathion peroxidase and catalase ${ }^{10}$.

In many mammalian species, up to $60 \%$ of the total fatty acids are long-chain polyunsaturated fatty acids of the $n-3$ and $n-6$ series. As a result of the oxidative stress, the polyunsaturated fatty acid membrane undergoes peroxidation, and the spermatozoa lose function ${ }^{11}$. Because lipid peroxidation may produce irreversible loss of sperm motility, it can serve as a biochemical index of semen quality ${ }^{11}$. Among cellular macromolecules, polyunsaturated fatty acids (PUFAs) exhibit the highest sensitivity to oxidative damage. It is accepted that such sensitivity increases as a power function of the number of double bonds per fatty acid molecule ${ }^{19}$. The measurement of lipid peroxidation is one of the most commonly used assays for induced damage in free radicals ${ }^{18,19}$.

A combination of ascorbate plus iron can trigger a Fenton-reaction with formation of highly reactive hydroxyl radicals, which may be the origin of a chain reaction of lipid peroxidation and secondary protein oxidation ${ }^{22}$. Ascorbate may enhance the process by keeping iron in the reduced state. In crude tissue fractions, iron in reduced form can degrade preformed lipid hydroperoxides, forming radicals that can catalyze the chain propagation phase of lipid peroxidation, without involving the hydroxyl radicals or other active oxygen species ${ }^{4}$. Lipid peroxidation termination involves the reaction of peroxide free radical (LOO') to form nonradical products or the reaction of one LOO with another terminating radical to generate non-propagating radical species. Some lipid peroxidation products are light-emitting species and their spontaneous chemiluminescence can be used as an internal marker of oxidative stress ${ }^{8}$.

Optimal sperm cryopreservation is a prerequisite for the sustainable commercial application of frozenthawed boar semen for artificial insemination ${ }^{20}$. The changes in viability, susceptibility to peroxidation and fatty acid composition of total phospholipid were studied in fresh boar spermatozoa obtained from two different farms.

The aim of this study was to determine fatty acid composition and to analyze the sensitivity to LP (ascorbate- $\mathrm{Fe}^{++}$dependent) in spermatozoa obtained from different samples of boar fresh semen from two herds (Herd 1= H1 La Plata) and (Herd $2=\mathrm{H} 2$ Entre Ríos). Light emission, chemiluminescence and fatty acid composition were used as markers of the oxidative destruction of lipids. The unsaturation index (UI), a parameter based on the maximal rate of oxidation of specific fatty acids, was used to evaluate fatty acid alterations observed during the process ${ }^{14}$. Therefore the ejaculates were evaluated by conventional semen characteristics: motility, viable cells, sperm abnormalities, and acrosomal integrity.

\section{MATERIAL AND METHODS}

Chemicals. Butylated hydroxytoluene (BHT) and phenyl-methyl-sulfonyl fluoride (PMSF) were from Sigma (St. Louis, MO, USA). Bovine serum albumin (BSA) (Fraction V) was obtained from Wako Pure Chemical Industries, Japan. L (+) ascorbic acid and boron-trifluoride-methanol complex were from Merck. Standards of fatty acids methyl esters were from $\mathrm{Nu}$ Check Prep Inc, Elysian, MN, USA. All other reagents and chemicals were of analytical grade from Sigma.

Animals, handling, evaluation and processing of ejaculates. Procedures involving animal handling and welfare were according to the recommendations of the Bioethics Committee of The National University of La Plata (Argentina). Fresh boar semen samples were obtained from two different farms from La Plata (Buenos Aires) and Entre Ríos, Argentina. Sperm rich ejaculate fractions (cross-breeding) obtained from three boars were collected by the gloved-hand technique, filtered with gauze and evaluated for conventional semen characteristics. The ejaculates use here showed progressive motility $>70 \%$, viable cells $>70 \%$, normal spermatozoa $>80 \%$ and normal acrosomal integrity $>80 \%$. Semen concentration was calculated by manual sperm cell count on a hemacytometer Bürker chamber. After evaluation, semen was diluted 1:4 in a commercial extender and transferred to $100 \mathrm{ml}$ tubes, containing a dose of 6 billion spermatozoa each, cooled to $17^{\circ} \mathrm{C}$, and sent by ordinary mail packaged in insulated containers under monitored temperature conditions. Samples arrived at the Reproduction Laboratory of the School of Veterinary Sciences (UNLP) the day after collection. At the laboratory, the semen was evaluated for semen quality: 1) percentage of progressively motile spermatozoa placed under a coverslip in the center of a prewarmed $37^{\circ} \mathrm{C}$ plate; 2) percentage of viable cells, by eosin-nigrosin staining; 3 ) percentage of normal spermatozoa morphology and of acrosomal integrity, by observing wet mounts of extended semen fixed in buffered $8 \%$ glutaraldehyde solution under a phase contrast microscope at a magnification of $1,000 \mathrm{x}$. An aliquot of each of fresh semen boar samples were sent to the Biochemistry Laboratory (Faculty of Veterinary Sciences, UNLP) for determine the fatty acid composition and to analyze sensitivity to lipid peroxidation. 
Preparation of fresh boar semen samples. An aliquot $(1 \mathrm{ml})$ of semen from each sample was centrifuged at $800 \mathrm{x} g$ for $10 \mathrm{~min}$, sperm pellets were separated, and washed by resuspending in PBS (phosphate buffer salinum) and recentrifuging (three times). After the last centrifugation, $1 \mathrm{ml}$ of deionized water was added to spermatozoa ${ }^{5}$, then snap-frozen to stored at $-83^{\circ} \mathrm{C}$ and used within a week of preparation, after one cycle of freezing and thawing. All operations were performed at $4^{\circ} \mathrm{C}$.

Non-enzymatic lipid peroxidation of spermatozoa. Chemiluminescence and lipid peroxidation were initiated by adding ascorbate- $\mathrm{Fe}^{++}$to spermatozoa preparations ${ }^{27}$. Spermatozoa samples ( $1 \mathrm{mg}$ of protein) were incubated at $37^{\circ} \mathrm{C}$ with $0.01 \mathrm{M}$ phosphate buffer $(\mathrm{pH}$ 7.4), $0.4 \mathrm{mM}$ ascorbate, $1 \mathrm{ml}$ final volume. Phosphate buffer was contaminated with sufficient iron to provide necessary ferrous or ferric iron for lipid peroxidation (final concentration in the incubation mixture was 2.15 $\mu \mathrm{M}){ }^{24}$. Spermatozoa preparations without ascorbate$\mathrm{Fe}^{++}$(controls) were carried out simultaneously. Chemiluminescence was measured as counts per min in a liquid scintillation analyzer Packard 1900 TR. Membrane light emission was determined over 120 min period, and recorded as cpm every $10 \mathrm{~min}$ and the sum of the total chemiluminescence was used to calculate $\mathrm{cpm} /$ mg protein. Lipid peroxidation is a branching chain reaction which can be considered as taking place in four main stages: (1) chain initiation, (2) chain propagation, (3) chain branching and (4) chain termination. At least three reactions are known to break the chains: (a) interaction of two radicals leading the chains, (b) interaction of one radical with changing metal valence, and (c) reaction between such a radical and a molecule of "antioxidant". $\mathrm{LO}_{2}{ }^{*}+\mathrm{LO}_{2}{ }^{*}(k) \rightarrow \mathrm{P}^{*} \rightarrow \mathrm{P}+\varphi h v$ (chemiluminescence). Reaction (a) is particularly interesting since it is accompanied by chemiluminescence which intensity $(I)$ may serve as a measure of peroxide free radical $\left(\mathrm{LO}_{2}{ }^{*}\right)$ concentration according to the equation: $I=K \varphi k\left[\mathrm{LO}_{2}{ }^{*}\right]^{2}$. Where $\varphi$ represents the chemiluminescence quantum yield and $k$ the coefficient depending on the net sensitivity of the instrument. $\mathrm{LO}_{2}{ }^{*}$ is a free radical produced from lipids molecules ${ }^{25}$.

Measurement of fatty acid composition. Spermatozoa lipids were extracted with chloroform/methanol ( $2: 1 \mathrm{v} / \mathrm{v}$ containing $0.01 \%$ BHT as antioxidant) from peroxidized membranes ${ }^{6}$. Fatty acids were transmethylated with $10 \% \mathrm{~F}_{3} \mathrm{~B}$ in methanol at $60^{\circ} \mathrm{C}$ for $3 \mathrm{~h}$. Fatty acid methyl esters were analyzed with a GC-14A gas chromatograph (Shimadzu, Kyoto, Japan) equipped with a packed column (1.80 m x $4 \mathrm{~mm}$ i.d.) GP $10 \%$ DEGS-PS on 80/100 Supelcoport. Nitrogen was used as the carrier gas. The injector and detector temperatures were maintained at $250^{\circ} \mathrm{C}$, the column temperature was held at $200^{\circ} \mathrm{C}$. Fatty acid methyl ester peaks were identified by comparison of the retention times with those of standards. All the compositions were expressed as \% by area of total fatty acids.

Unsaturation index. Unsaturation index (UI) was calculated according to the formula, UI=sum (fatty acid percent) $x$ (number of double bonds) ${ }^{14}$.

Protein determination. Proteins were determined by the Method of Lowry using BSA as standard ${ }^{16}$.

Statistical analysis. The data were subjected to the Student's t-test. Data were expressed as mean \pm SD. The 0.05 level was selected as the point of minimal statistical significance. Data were expressed as means \pm SD. Statistical analysis utilized was Student's t-test. Statistical criterion for significance was selected at different $p$ values and indicated in each case.

\section{RESULTS}

The fatty acid composition of total lipids isolated from different spermatozoa samples (control and peroxidized) is shown in Table 1. In all the examined samples, the fatty acid profile was different. The saturated long chain fatty acids present in spermatozoa were mainly palmitic acid (C16:0) and stearic acid (C18:0) in a percentage of approximately $43 \%$ (H1) and $33 \%$ (H2). The concentration of total unsaturated fatty acids of spermatozoa was approximately $47 \%$ (H1) and $59 \%$ (H2) with a high percentage of long chain polyunsaturated fatty acids as docosapentaenoic acid (C22:5 n6) and docosahexaenoic acid (22:6 n3). In Figure 1 a) and b) it was represented the differential percentage of the major polyunsaturated fatty acids presents in $\mathrm{H} 1$ and $\mathrm{H} 2$.

a

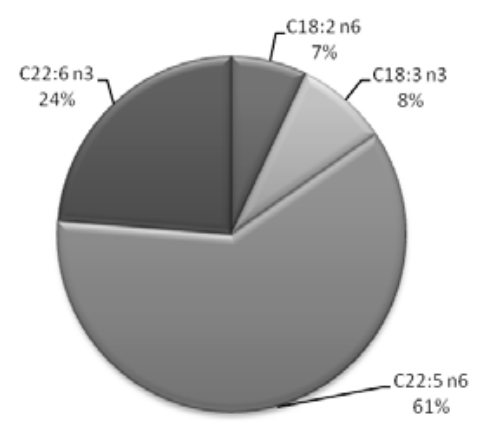

b

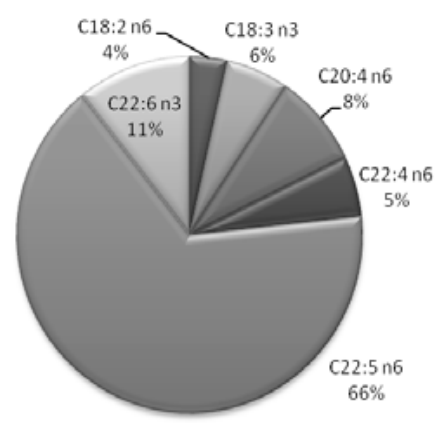

Figure 1. Polyunsaturated fatty acid profile represented as area porcentual in a) $\mathrm{H} 1$ and b) $\mathrm{H} 2$. 
Table 1. Fatty acid composition of fatty acids present in the spermatozoa lipids of boar in herds $\mathrm{H} 1$ and $\mathrm{H} 2$.

\begin{tabular}{lcccc}
\hline \multirow{2}{*}{ fatty acids } & \multicolumn{2}{c}{ group H1 } & \multicolumn{2}{c}{ group H2 } \\
\cline { 2 - 5 } C16:0 & control & peroxidized & control & peroxidized \\
C 16:1 n7 & $31.06 \pm 3.80$ & $42.94 \pm 6.98$ & $21.90 \pm 3.46$ & $42.93 \pm 5.64$ \\
C18:0 & $5.82 \pm 2.79$ & $4.02 \pm 1.26$ & $\mathrm{Nd}$ & $\mathrm{Nd}$ \\
$\mathrm{C} 18: 1 \mathrm{n} 9$ & $11.98 \pm 4.26$ & $6.19 \pm 2.43$ & $11.09 \pm 5.65$ & $17.01 . \pm 3.39$ \\
$\mathrm{C} 18: 2 \mathrm{n} 6$ & $15.43 \pm 6.49$ & $20.43 \pm 2.91$ & $4.63 \pm 0.68$ & $18.35 \pm 8.14$ \\
$\mathrm{C} 18: 3 \mathrm{n} 3$ & $2.48 \pm 1.25$ & $2.58 \pm .1 .20$ & $2.15 \pm 1.24$ & $5.27 \pm 2.19$ \\
$\mathrm{C} 20: 4 \mathrm{n} 6$ & $2.98 \pm 1.22$ & $2.38 \pm 0.43$ & $3.60 \pm 0.51$ & $8.21 \pm 0.23$ \\
C22:4 $n 6$ & $\mathrm{Nd}$ & $\mathrm{Nd}$ & $5.20 \pm 2.29$ & $1.57 \pm 0.40 *$ \\
C22:5n6 & $\mathrm{Nd}$ & $\mathrm{Nd}$ & $3.33 \pm 0.99$ & $0.77 \pm 0.25 *$ \\
C22:6n3 & $21.43 \pm 4.34$ & $10.67 \pm 3.43$ & $40.44 \pm 1.15$ & $4.57 \pm 1.14 * * *$ \\
& $8.39 \pm 2.92$ & $4.44 \pm 0.40^{*}$ & $6.55 \pm .1 .16$ & $1.83 \pm 0.1 * *$ \\
saturated & & & $32.99 \pm 9.11$ & $59.94 \pm 8.80^{*}$ \\
monounsaturated & $43.04 \pm 7.28$ & $59.13 \pm 9.02$ & $4.63 \pm 0.68$ & $18.35 \pm 10.14$ \\
polyunsaturated & $21.25 \pm 6.94$ & $24.45 \pm 2.75$ & $54.72 \pm 5.17$ & $20.37 \pm 2.16^{* * *}$ \\
total unsaturated. & $26.06 \pm 4.02$ & $15.63 \pm 3.48^{*}$ & $59.36 \pm 5.74$ & $38.72 \pm 8.91^{*}$ \\
saturated/unsaturated & $47.31 \pm 7.52$ & $40.08 \pm 2.85$ & $0.57 \pm 0.19$ & $1.62 \pm 0.51^{*}$ \\
UI & $0.94 \pm 0.30$ & $1.49 \pm 0.31$ & $256.07 \pm 19.5$ & $85.67 \pm 11.01^{* * *}$ \\
\hline
\end{tabular}

Results are expressed as mean \pm SD of three independent experiments. Statistically significant differences between control vs peroxidized samples are indicated by $* p<0.05, * * p<0.005, * * * p<0.0005$.

The fatty acid profile was markedly modified by peroxidation, PUFA content decreased and concomitantly saturated fatty acid percentage increased. A substantial difference was found in the content of the main peroxidable fatty acids $\mathrm{C} 22: 5 \mathrm{n} 6$ and $\mathrm{C} 22: 6 \mathrm{n} 3$ in both herds (Figure 2) whereas C20:4 n6 y C22:4 n6 only in $\mathrm{H} 2$ (Table 1), showing significant decreases as expected when the lipid peroxidation process occurs. The UI showed significant differences between control and peroxidized samples in both herds (Table 1).

Spermatozoa membranes incubation in the presence of ascorbate- $\mathrm{Fe}^{++}$led to membrane phospholipids peroxidation as evidenced by light emission (chemiluminescence) and PUFAs decrease, mainly C22:5 n6. Changes in the fatty acid profiles were used as an index of the oxidative damage to lipids. Figure 3 shows

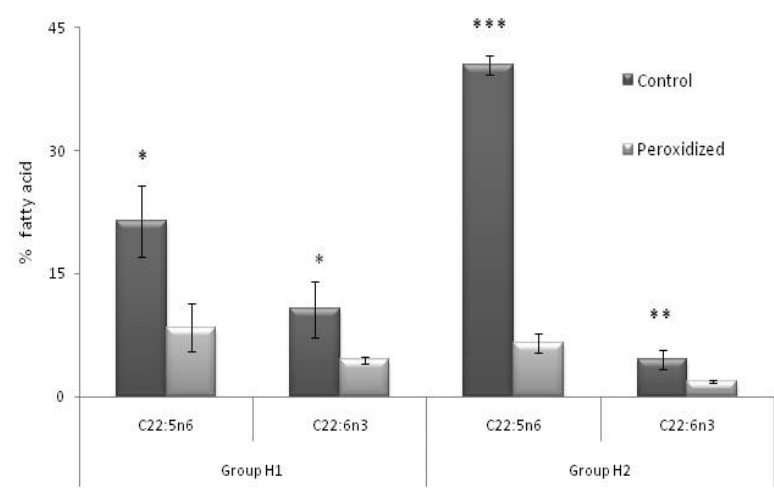

Figure 2. Comparison of the main unsaturated fatty acids in the spermatozoa lipids of boar in herds H1 and $\mathrm{H} 2$ (mean $\pm \mathrm{SD}$ ). Statistically significant differences between control vs peroxidized samples are indicated by $* p<0.05,{ }^{* *} p<0.005$ and $* * * p<0.0005$. the total chemiluminescence (sum of all the readings obtained every $10 \mathrm{~min}$ for $120 \mathrm{~min}$ a $37^{\circ} \mathrm{C}$ ). Total chemiluminescence increased from $179.67 \pm 48.12 \mathrm{cpm}$ in control (without ascorbate) up to $475 \pm 74.1 \mathrm{cpm}$ in peroxidized (with ascorbate- $\mathrm{Fe}^{++}$) groups $\mathrm{H1}, 201.63 \pm$ $8.25 \mathrm{cpm}$ in control (without ascorbate) up to $865.17 \pm$ 26.63 in peroxidized (with ascorbate- $\mathrm{Fe}^{++}$) groups $\mathrm{H} 2$. Therefore, the value of the lipid peroxidation process, measured as total light emission during non enzymatic lipid peroxidation, was 4 fold higher in ascorbate- $\mathrm{Fe}^{++}$ than control group in $\mathrm{H} 2$.

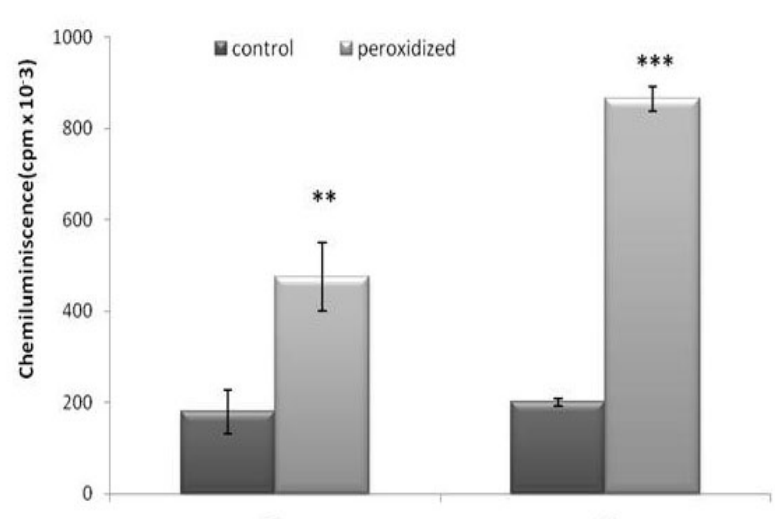

E1

E2

Figure 3. Lipid peroxidation ascorbate- $\mathrm{Fe}^{2+}$ of boar spermatozoa. Chemiluminescence was determined over a $120 \mathrm{~min}$ period and recorded as cpm every 10 $\mathrm{min}$ and the sum of the total chemiluminescence was used to calculate $\mathrm{cpm} / \mathrm{mg}$ protein (mean $\pm \mathrm{SD}$ ). Statistically significant differences between control and peroxidized are indicated by ${ }^{* *} p<0.005$ and ${ }^{* * *} p$ $<0.0005$. 
After arriving at the Reproduction Lab, seminal parameters of diluted semen were different between groups $\mathrm{H} 1$ and $\mathrm{H} 2$. Although the percentage of progressive motility was similar, percentage of viable cells decreased in group H1, while percentage of acrosomal integrity was major in $\mathrm{H} 1$ than in $\mathrm{H} 2$. Only $1 \%$ of abnormal morphology (curl tail) was found in H1 (Figure 4).

\section{DISCUSSION}

A high percentage of polyunsaturated fatty acids is required by spermatozoa membrane to build up a high fluid microenvironment to lead fertilization process. The phospholipids of spermatozoa of all species contain large amounts of PUFAs. The n-3 and n-6 PUFAs are considered to be essential due the inability of vertebrates to synthesize them. The $n-3$ series docoxahexaenoic acid dominates the lipid make up of mammalian spermatozoa ${ }^{13}$. Even though level and combinations of fatty acids of n- 6 and $n-3$ series in the phospholipid fractions demonstrate different specificity, the final total level of unsaturation of male gamete lipid was always high.

In this study, we demonstrated that unsaturated and polyunsaturated fatty acids were different in spermatozoa groups $\mathrm{H} 1$ and $\mathrm{H} 2$, something being similar with dog semen ${ }^{7}$. When we compared $\mathrm{H} 1$ with $\mathrm{H} 2$ groups we observed that spermatozoa samples of $\mathrm{H} 2$ possess higher content of polyunsaturated fatty acids, mainly C22:5 n6, C22:6 n3, C22:4 n6, and C20:4 n6. The fatty acid profiles of spermatozoa of boar exhibit high levels of C22:5 n6 and C22:6 n3, similar to dog semen ${ }^{7}$.

Lipid peroxidation is recognized as a damaging process to spermatozoa, leading to motility loss and reduced fertilizing ability in spermatozoa of many species, including man ${ }^{1}$. Lipid peroxidation occurs spontaneously in mammalian spermatozoa ${ }^{12}$ and is

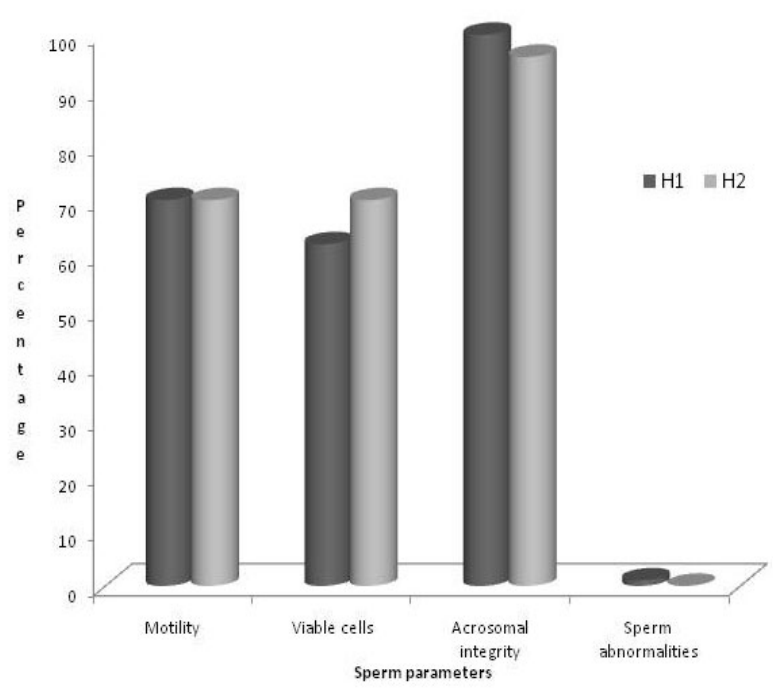

Figure 4. Sperm parameters (motility, viable cells, acrosomal integrity and sperm abnormalities) in $\mathrm{H} 1$ (Buenos Aires Province) vs H2 (Entre Ríos Province). greatly enhanced in human sub-fertile ejaculates ${ }^{2}$ or fowl stored semen ${ }^{1,26}$. The mechanisms by which ROS disrupt the sperm function are believed to involve the peroxidation of the polyunsaturated fatty acids present in the sperm plasma membrane and this process plays an important role in the pathophysiology of male infertility ${ }^{1}$. ROS increase DNA fragmentations ${ }^{1}$, modify the cytoskeleton ${ }^{15}$, affect the sperm axoneme development ${ }^{9}$ and inhibit sperm-oocyte fusion.

Individual acyl chains differ greatly in their chemical propensity to oxidative damage ${ }^{1}$. The n-3 PUFAs are more peroxidative-prone than n-6 PUFAs and within each PUFA class there is 4-fold increase in peroxidizability between short and long-chain fats, C22:6 n3 is 320 -fold more susceptible to peroxidation than $18: \ln 9$ ${ }^{23}$. The high content of unsaturated fatty acids of boar spermatozoa is correlated with the vulnerability to lipid peroxidation observed in the semen, which showed a positive correlation with the level of long-chain polyunsaturated fatty acid and high values of light emission.

Lipid peroxidation can alter the cellular structure of membrane-bound enzymes by changing the composition of membrane phospholipids fatty acid. Lipid peroxidation has gained renewed attention because of increasing evidence showing its biological role in aging animals. The assessment of lipid peroxidation levels in vivo is difficult partly because lipids are oxidized and oxidants by different mechanisms which give versatile types of products, that may undergo metabolism and secondary reactions ${ }^{28}$.

Chemiluminescence is the light emission derived from a chemical reaction such as the last reaction of lipid peroxidation in which chemically excited molecules decay to the electronic ground state and emit photons. Measurement of light emission from a chemical reaction is very useful from an analytical point of view because, under appropriate experimental conditions, light output is directly related to analytic concentration, thus allowing precise and sensitive quantitative analysis. In addition, light emission is usually represented by steady-state kinetics, which simplifies sample handling and measurement procedures. Chemiluminescence has widely been used as an indicator of reactive oxygen species formation in cells and whole organs, thus allowing the study of a number of pathophysiological conditions related to oxidative stress ${ }^{21}$.

Many studies have shown that free radical damage and lipid peroxidation increased as a function of the degree of unsaturation of the fatty acid substrates present in the tissues in vivo ${ }^{19}$. In addition, lipid peroxidation products are known to damage nearby macromolecules including DNA ${ }^{3}$, with expected long-term consequence for aging ${ }^{19}$.

The great content of highly polyunsaturated fatty acids of spermatozoa group $\mathrm{H} 2$ is correlated with the vulnerability to lipid peroxidation observed in this group with higher values of light emission than to control spermatozoa samples. However, spermatozoa group H1 possesses a high concentration of polyun- 
saturated fatty acids that showed to be resistant to lipid peroxidation. It is interesting to note that spermatozoa group H1 showed an increase of 18:2 n6, 18:3 n3 and monounsaturated acids content, in parallel with a decrease in 20:4 n6 fatty acid when compared to spermatozoa group $\mathrm{H} 2$. These differences and other factors may be involved in less sensitivity to lipid peroxidation shown by spermatozoa group H1.

When we analyzed the functional activity of sperm cells there was not significant differences regarding motility in spermatozoa samples from both herds (H1 and H2). This fact is correlated with the presence of high levels of C22:5 n6 and C22:6 $\mathrm{n} 3$ fatty acids in all samples. The low sperm viability observed in $\mathrm{H} 1$ could be related with the minor percentage of polyunsaturated fatty acids. The presence of ROS in sperm samples produced an increase of permeability in plasmatic and acrosomal membranes. The spermatozoa samples of $\mathrm{H} 2$ were more affected by lipid peroxidation process and consequently, showed high percentage of acrosomal damage.

In conclusion, our results allow to determine a great variability in the polyunsaturated fatty acid composition in boar spermatozoa from both herds. Therefore, this variability was observed when different samples were submitted to non-enzymatic lipoperoxidation assays. Semen samples from herd 2 had more susceptibility to the lipid peroxidation process. These preliminary results indicate that boar semen contains great amounts of PUFA, which were vulnerable to lipoperoxidation and alteration in their composition will be the common base of different degenerative processes. Therefore seminal parameters analyzed in diluted semen were different between the two groups according with the great variability in fatty acid composition between both herds.

Acknowledgements. This work was supported by Secretaría de Ciencia y Técnica, National University of La Plata ( Proyecto V191), Argentina.

\section{REFERENCES}

1. Aitken RJ. 1994. A free radical theory of male infertility. Reprod Fertil Dev 6: 19-24.

2. Alvarez JC, Storey BT. 1989. Role of gluthatione peroxidase in protecting mammalian spermatozoa from loss of motility caused by spontaneous lipid peroxidation. Gamete Res 23: 77-90.

3. Box H, Maccubin A. 1997. Lipid peroxidation and DNA damage. Nut 13: 920-921.

4. Chakraborty H, Ray SN, Chakrabarti S. 2001. Lipid peroxidation associated protein damage in rat brain crude synaptosomal fraction mediated by iron and ascorbate. Neurochem Int 39: 311-317.

5. Dandekar SP, Nadkami GD, Kulkami VS, Punekar S. 2002. Lipid peroxidation and antioxidant enzymes in male infertility. J Posgrad Med 48: 186-189.
6. Folch J, Lees N, Sloane GA. 1957. A simple method for the isolation and purification of total lipids from animal tissues. J Biol Chem 226: 497-509.

7. Gavazza M, Gutiérrez AM, Marmunti M, Palacios A. 2009. Lipid peroxidation assays in canine fresh semen. Rev Vet 20: 97-102.

8. Havaux M. 2003. Spontaneous and thermo induced photon emission: new methods to detect and quantify oxidative stress in plants. Trends Plant Sci 8: 409-413.

9. Hinshaw DB, Sklar LA, Bohl B. 1986. Cytoeskeletal and morphologic impact of cellular oxidant injury. $\mathrm{Am} \mathrm{J}$ Pathol 123: 454-464.

10. Irvine DS, Aitken RJ. 1994. Seminal fluid analysis and sperm function testing. Endocrinol Metab Clin North Am 23: 725-748.

11. Jones R, Mann T, Sherins RJ. 1979. Peroxidative breakdown of phospholipids in human spermatozoa. Spermicidal properties of fatty acid peroxides and protective action of seminal plasma. Fertil Steril 31: 531-537.

12. Lenzi A, Gandini L, Picardo M, Tramer F, Sandri G, Panfili E. 2000. Lipoperoxidation damage of spermatozoa polyunsaturated fatty acids (PUFA): Sacavenger mechanism and possible therapies. Front Biosci 5: E1-E2.

13. Lin DS, Connor WE, Wolf DP, Neuringer M, Hachey DL. 1993. Unique lipids of primate spermatozoa: desmosterol and DHA. J Lipid Res 34: 491-499.

14. Llanillo M, Sánchez-Yague J, Checa A, Martín-Valmaseda EM, Felipe A. 1995. Phospholipid and fatty acid composition in stored sheep erythrocytes of different densities. Exp Hematol 23: 258-264.

15. Lopes S, Jurisicova A, Sun JG, Casper RF. 1998. Reactive oxygen species: potential cause for DNA fragmentation in human spermatozoa. Hum Reprod 13: 896-900.

16. Lowry OH, Rosebrough NJ, Farr AL, Randall RJ. 1951. Protein measurement with the Folin phenol reagent. J Biol Chem 193: 265-275.

17. Membrilo-Ortega A, Córdova Izquierdo A, Hicks Gómez JJ, Olivares-Corichi M, Martinez Torres VM, Valencia Mendez J. 2003. Peroxidación lipídica y antioxidantes en la preservación de semen. Interciencia 28: 699704.

18. Ozgova S, Hermanek J, Gut I. 2003. Different antioxidant effects of polyphenols on lipid peroxidation and hydroxyl radicals in the NADPH, Fe- ascorbate and Fe microsomal systems. Biochem Pharmacol 66: 1127-1137.

19. Pamplona R. 2008. Membrane phospholipids, lipoxidative damage and molecular integrity: a causal role in aging and longevity. Biochim Biophys Acta 1777: 1249-1262.

20. Roca J, Gil M, Hernandez M, Parrilla I, Vazquez JM, Martinez E. 2004. Survival and fertility of boar spermatozoa after freeze-thawing in extender supplemented with butylated hydroxytoluene. J Androl 25: 397-405.

21. Roda A, Pasini P, Guardigli M, Baraldini M, Musiani M, Mirasoli M. 2000. Bio and chemiluminescence in bioanalysis. J Anal Chem 366: 752-759.

22. Spiteller G. 2003. Are lipid peroxidation processes induced by changes in the cell wall structure and how are these processes connected with diseases? Med Hypotheses 60: 69-83. 
23. Surai PF, Kutz E, Whishart GH, Noble RC, Speake BK. 1997. The relationship between the dietary provision of alfa-tocopherol and the concentration of this vitamin in the semen of chicken: effects on lipid composition and susceptibility to peroxidation. $J$ Reprod Fertil 110: 47-51.

24. Terrasa A, Guajardo M, Catalá A. 2000. Selective inhibition of the non-enzymatic lipid peroxidation of phosphatidylserine in rod outer segments by alpha-tocopherol. Mol Cell Biochem 211: 39-45.

25. Vladimirov YA, Olenev VI, Suslova TB, Cheremisina ZP. 1980. Lipid peroxidation in mitochondrial membrane. Adv Lipid Res 17: 173-249.
26. Wishart GJ. 1989. Physiological changes in fowl and turkey spermatozoa during in vitro storage. Br Poult Sci 30: 443-454.

27. Wright JR, Rumbaugh RC, Colby HD, Miles PR. 1979. The relationship between chemiluminescence and lipid peroxidation in rat hepatic microsomes. Archiv Biochem Biophys 192: 344-351.

28. Yoshida Y, Saito Y, Hayakawa M. 2007. Levels of lipid peroxidation in human plasma and erythrocytes: comparison between fatty acids and cholesterol. Lipids 42: 439449.

\section{Revista Veterinaria obtuvo el máximo nivel de categorización del CAICYT-CONICET}

Tras el pertinente proceso de evaluación según criterios de calidad editorial, en setiembre de 2005 CAICYT-CONICET ha clasificado a nuestra publicación con Categoría 1 (nivel superior de excelencia), con lo cual pasa a integrar el Catálogo Latindex (folio 14022). La Dirección de Revista veterinaria agradece a quienes colaboraron para obtener tan importante distinción. Ver: http://www.latindex. unam.mx/busquedas/catalogotitulo.html 